\title{
Partial Purification of Plasma Thromboplastin Antecedent (Factor XI) and its Activation by Trypsin
}

\author{
Hidehiko Satto, Oscar D. Ratnoff, James S. Marshall, and \\ JaCk Pensky \\ From the Department of Medicine, Case Western Reserve University School of \\ Medicine, and University Hospitals of Cleveland, Cleveland, Ohio 44106
}

\begin{abstract}
A B S T R A C T A persistent puzzle in our understanding of hemostasis has been the absence of hemorrhagic symptoms in the majority of patients with Hageman trait, the hereditary deficiency of Hageman factor (factor XII). One proposed hypothesis is that alternative mechanisms exist in blood through which plasma thromboplastin antecedent (PTA, factor XI) can become active in the absence of Hageman factor. In order to test this hypothesis, the effect of several proteolytic enzymes, among them thrombin, plasma kallikrein, and trypsin, was tested upon unactivated PTA. PTA was prepared from normal human plasma by $\mathrm{Ca}_{3}\left(\mathrm{PO}_{4}\right)_{2}$ adsorption, ammonium sulfate fractionation, and successive chromatography on QAE-Sephadex (twice), SephadexG150, and SP-Sephadex. The partially purified PTA was almost all in its native form, with a specific activity of $45-70 \mathrm{U} / \mathrm{mg}$ protein; the yield was about $10 \%$. It contained no measurable amounts of other known clotting factors, plasmin, plasminogen, nor IgG. Incubation of PTA with trypsin generated potent clot-promoting activity that corrected the abnormally long clotting time of plasma deficient in Hageman factor or PTA but not in Christmas factor. This clot-promoting agent behaved like activated PTA on gel filtration (apparent molecular weight: 185,000) and was specifically inhibited by an antiserum directed against activated PTA. These data suggested that PTA can be converted into its active form by trypsin. PTA was not activated by thrombin, chymotrypsin, papain, ficin, plasmin, plasma kallikrein, tissue thromboplastin, or $\mathrm{C} \overline{1}$. Trypsin converted PTA to its active form enzymatically. Whether trypsin serves to activate PTA in vivo is not yet clear.
\end{abstract}

Dr. Saito is a Research Fellow and Dr. Ratnoff is a Career Investigator of the American Heart Association.

Received for publication 9 October 1972 and in revised form 27 November 1972.

\section{INTRODUCTION}

The first recognized step in the coagulation of plasma in glass tubes via the so-called intrinsic pathway is the activation of Hageman factor (factor XII). In turn, activated Hageman factor converts another clotting factor, plasma thromboplastin antecedent (PTA, Factor XI) ${ }^{1}$ to activated PTA, probably by an enzymatic process $(1,2)$. Although human activated PTA has been highly purified and its properties studied extensively (3), similar separation of PTA, its precursor, has been more difficult to achieve. The present study concerns the separation of PTA and some of its properties. A persistent puzzle in our understanding of hemostasis has been the dearth of hemorrhagic symptoms in the great majority of patients with Hageman trait, the hereditary deficiency of Hageman factor (4). One proposed hypothesis is that alternative mechanisms exist in blood through which PTA can become active in the absence of Hageman factor. To examine this possibility, several proteolytic enzymes such as thrombin, plasma kallikrein, and trypsin were tested for their ability to activate PTA.

Evidence will be presented that PTA can be changed to its activated form enzymatically by bovine trypsin, a phenomenon also reported by Wuepper (5) while these studies were in progress.

\section{MATERIALS}

Venous blood was drawn by gravity from the antecubital veins of normal human subjects, using a no. 15 gauge needle attached to plastic tubing which had been coated with silicone oil (SF-96 (200), Harwick Standard Chemical Co., Akron, Ohio). The blood was mixed in polypropylene bottles with ioth vol of $0.1 \mathrm{M}$ sodium oxalate solution, and

${ }^{1}$ Abbreviations used in this paper: LBTI, lima bean trypsin inhibitor; PTA, plasma thromboplastin antecedent (factor XI) ; TAME, $p$-toluenesulfonyl-L-arginine methyl ester. 


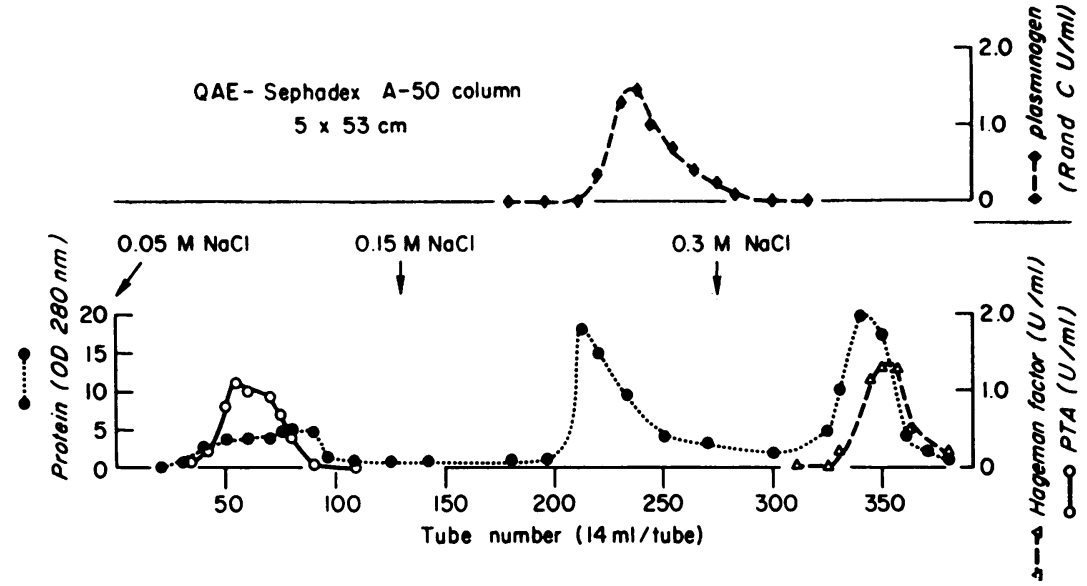

FIGURE 1 The chromatography of the $20-60 \%$ ammonium sulfate fraction of normal calcium phosphate-adsorbed plasma on a QAE-Sephadex A-50 column. The protein was eluted from the column using a stepwise $\mathrm{NaCl}$ gradient $(0.05,0.15$, and $0.3 \mathrm{M}$, as indicated by arrows) in $0.025 \mathrm{M}$ Tris buffer ( $\mathrm{pH} 8.0$ ) containing $0.0001 \mathrm{M}$ EDTA and $0.05 \mathrm{mg}$ of Polybrene $/ \mathrm{ml}$. PTA activity was present in those fractions that were eluted by the starting buffer containing $0.05 \mathrm{M} \mathrm{NaCl}$.

platelet-deficient plasma separated by two successive centrifugations at $16,300 \mathrm{~g}$ for $20 \mathrm{~min}$ each. Citrated human plasma deficient in one or another clotting factor and bovine PTA-deficient plasma (6) were obtained as described earlier (7). A standard pool of 25 normal human plasmas was prepared by an earlier method (8).

Partially purified PTA was prepared from pools of approximately 1 liter of oxalated normal human plasma to which 100th vol of $0.01 \mathrm{M}$ disodium ethylenediaminetetraacetic acid (EDTA) and $5 \mathrm{mg}$ of hexadimethrine bromide (Polybrene, Aldrich Chemical Co., Inc., Milwaukee, Wis.) per $\mathrm{ml}$ were added. The Polybrene served to prevent activation of PTA during the early steps of purification. The plasma was adsorbed with $7 \mathrm{mg}$ of tricalcium phosphate (J. T. Baker Chemical Co., Phillipsburg, N. J.) per $\mathrm{ml}$ for $10 \mathrm{~min}$ at room temperature, using a magnetic stirrer; this procedure reduced the plasma's content of prothrombin (factor II), Stuart factor (factor X), factor VII, and Christmas factor (factor IX). The calcium phosphate was removed by centrifugation at $16,300 \mathrm{~g}$ for $10 \mathrm{~min}$. The supernatant plasma was fractionated with neutral ammonium sulfate (Merck Chemical Div., Merck \& Co., Inc., Rahway, N. J.) solution, saturated at $4^{\circ} \mathrm{C}$, and containing $0.0001 \mathrm{M}$ EDTA and $0.05 \mathrm{mg}$ of Polybrene per $\mathrm{ml}$. The fraction soluble at $20 \%$ saturation and insoluble at $60 \%$ saturation was dissolved in $0.025 \mathrm{M}$ tris(hydroxymethyl)-aminomethane$\mathrm{HCl}$ (Tris) buffer $\left(\mathrm{pH} 8.0\right.$ at $\left.4^{\circ} \mathrm{C}\right)$, containing $0.05 \mathrm{M}$ sodium chloride, $0.0001 \mathrm{M}$ EDTA, and $0.05 \mathrm{mg}$ Polybrene per $\mathrm{ml}$, the dialyzed overnight against two changes of 20 vol of the same buffer. The dialyzed solution was centrifuged for $10 \mathrm{~min}$ at $16,300 \mathrm{~g}$, and the precipitate was discarded. The clear supernatant fluid was divided in half, and each portion was applied to a $5 \times 53 \mathrm{~cm}$ silicone-coated glass chromatographic column containing QAE-Sephadex A-50 (Pharmacia Fine Chemicals, Inc., Piscataway, N. J.) previously equilibrated with $0.025 \mathrm{M}$ Tris buffer ( $\mathrm{pH} 8.0$ ) containing sodium chloride, EDTA, and Polybrene, as described above. The columns were each eluted with 2 liters of equilibrating buffer, and approximately 14-ml fractions were collected in cellulose nitrate or polystyrene tubes at a rate of $50-70 \mathrm{ml} / \mathrm{h}$. PTA-like material, in the precursor form, was present in those fractions that did not adhere to the columns and was separated from Hageman factor and plasminogen, which were eluted at higher ionic strength (Fig. 1). The PTA-rich fractions, which contained prekallikrein and IgG, were concentrated by the addition of solid ammonium sulfate to $60 \%$ saturation. After $2 \mathrm{~h}$, the precipitates of eluates of the two columns were dissolved in $0.025 \mathrm{M}$ Tris buffer ( $\mathrm{pH} 8.0$ ) containing 0.0001 M EDTA and $0.05 \mathrm{mg}$ Polybrene per $\mathrm{ml}$, combined, and dialyzed against two changes of $20 \mathrm{vol}$ of the same buffer overnight. The dialyzed solution was cleared of undissolved precipitate by centrifugation at $800 \mathrm{~g}$ for $10 \mathrm{~min}$ and applied to a second QAE-Sephadex A-50 column $(2.5 \times 35 \mathrm{~cm})$, equilibrated with the same buffer. The column was eluted with the starting buffer, and again PTA-like material was present in fractions not adsorbed to the column. This second QAESephadex A-50 column did not increase the specific activity of the PTA appreciably but served to remove traces of Hageman factor and plasminogen that escaped the first fractionation. The contents of tubes containing PTA were pooled, concentrated by the addition of solid ammonium sulfate to $60 \%$ saturation, dissolved in $0.025 \mathrm{M}$ Tris buffer ( $\mathrm{pH}$ 8.0) containing $0.15 \mathrm{M}$ sodium chloride, $0.0001 \mathrm{M}$ EDTA, and $0.05 \mathrm{mg}$ Polybrene per $\mathrm{ml}$, and dialyzed overnight against two changes of $20 \mathrm{vol}$ of the same buffer. The PTA-rich solution (approximately 20-30 ml) was divided in two and was filtered through a $5 \times 86 \mathrm{~cm}$ column of Sephadex G-150 (Pharmacia Fine Chemicals, Inc.), preswollen in the same buffer. Samples of $10-15 \mathrm{ml}$ were applied, and the column was eluted with the starting buffer, at a rate of $50 \mathrm{ml} / \mathrm{h}$, collecting $6-\mathrm{ml}$ fractions (Fig. 2). Tubes containing the greatest amount of PTA-like material were pooled and solid ammonium sulfate was added to $60 \%$ saturation. The precipitate that formed was dissolved and dialyzed against $0.05 \mathrm{M}$ sodium acetate buffer ( $\mathrm{pH} 5.2$ ) 


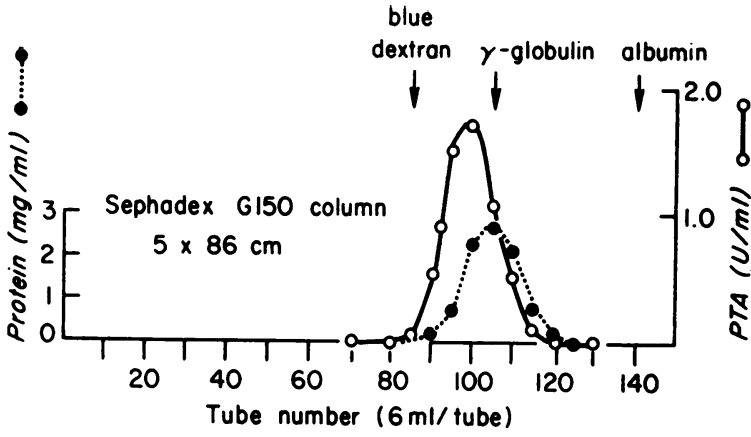

FIgURE 2 The chromatography of PTA on a Sephadex G150 column. After concentration to approximately $30 \mathrm{ml}$, half of the PTA fraction prepared as illustrated in Fig. 1 was applied and the column was eluted with $0.025 \mathrm{M}$ Tris buffer ( $\mathrm{pH} 8.0$ ) containing $0.15 \mathrm{M} \mathrm{NaCl}, 0.0001 \mathrm{M}$ EDTA and $0.05 \mathrm{mg}$ Polybrene $/ \mathrm{ml}$. Arrows indicate the peak of maximal elution of three markers (blue dextran, bovine $\gamma$ globulin and bovine albumin ).

containing $0.15 \mathrm{M}$ sodium chloride and $0.0001 \mathrm{M}$ EDTA. At this and subsequent steps, no Polybrene was added, as spontaneous activation of PTA no longer occurred in its absence, presumably because Hageman factor had been effectively removed. Ammonium sulfate precipitation was repeated a second time to remove trace amounts of Polybrene. The dialyzed solution was then applied to a $2.5 \times 37$ cm column of SP-Sephadex C-50 (Pharmacia Fine Chemicals, Inc.) previously equilibrated with the acetate-sodium chloride-EDTA buffer, and the column was eluted with the equilibrating buffer until protein not adhering to the column had been removed. A linear salt gradient of $500 \mathrm{ml}$ each of the starting buffer and $0.05 \mathrm{M}$ sodium acetate buffer ( $\mathrm{pH}$ 5.2) containing $0.5 \mathrm{M}$ sodium chloride and 0.0001 $M$ EDTA was then applied at a rate of $20-30 \mathrm{ml} / \mathrm{h}$, and $7-\mathrm{ml}$ fractions were collected. PTA-like material was eluted after the second protein peak, at concentrations between 0.30 and $0.34 \mathrm{M}$ sodium chloride (Fig. 3). Fractions containing PTA were pooled, concentrated to approximately 8 $\mathrm{ml}$ in an Amicon ultrafiltration cell (Amicon Corp., Lexington, Mass.) using a PM-10 Diaflo membrane, and dialyzed against barbital-saline buffer. The PTA preparation was still in the precursor form and had a specific activity of $45-70 \mathrm{U} / \mathrm{mg}$ protein ( $1 \mathrm{U}$ being that amount found in $1 \mathrm{ml}$ of a standard pool of normal human-citrated plasma) (4) ; the yield was approximately $10 \%$ of the starting material. At a concentration of $2 \mathrm{U} / \mathrm{ml}$, it contained no detectable Hageman factor, Christmas factor, antihemophilic factor (factor VIII), factor VII, Stuart factor, proaccelerin (factor V), prothrombin, thrombin, fibrinogen, plasminogen, or plasmin, using techniques described in the section on Methods. IgG was not detectable in a solution of PTA containing $7 \mathrm{U} / \mathrm{ml}$, as tested by immunodiffusion against specific goat antiserum. A preparation with a specific activity of $70 \mathrm{U} / \mathrm{mg}$ of protein contained trace amounts of Hageman factor cofactor (7) and small amounts of $p$-toluenesulfonyl-L-arginine methyl ester (TAME) esterase activity $(1.2 \mu \mathrm{M}$ of methanol released/h per unit of PTA) detected by treatment with Enzite-trypsin in the manner to be described, but it has no kallikrein-like activity detectable in a rat uterus assay after the same trypsin treatment.

Bovine fibrinogen (fraction I, ICN Nutritional Biochemicals Div., International Chemical \& Nuclear Corp., Cleveland,
Ohio), containing approximately $50 \%$ sodium citrate and $60 \%$ coagulable protein, was dissolved at a concentration of $1.5 \%$ in barbital-saline buffer.

p-Toluenesulfonyl-L-arginine methyl ester (TAME) was obtained from Nutritional Biochemicals Div., and dissolved in $0.067 \mathrm{M}$ sodium phosphate buffer ( $\mathrm{pH} 7.5$ ) containing $0.6 \%$ sodium chloride.

Purified human thrombin was the generous gift of Dr. Kent Miller, Division of Laboratories and Research, New York State Department of Health. The thrombin used had a specific activity of $1160 \mathrm{NIH} \mathrm{U/mg} \mathrm{protein} \mathrm{and} \mathrm{was} \mathrm{free}$ of detectable plasmin, plasminogen, and plasminogen activator. Hageman factor was also not detectable in this preparation, as tested by immunodiffusion against rabbit antiserum to human Hageman factor.

Partially purified bovine thrombin was prepared from crude Topical thrombin (Parke, Davis \& Company, Detroit, Mich.) by successive column chromatography on AmberliteGC50 (9), QAE-Sephadex A-50, and Sephadex G150. The Amberlite-thrombin prepared from $5000 \mathrm{NIH} U$ of Topical thrombin was dialyzed against $0.025 \mathrm{M}$ Tris buffer ( $\mathrm{pH} 8.0$ ) containing $0.1 \mathrm{M} \mathrm{NaCl}$ and $0.0001 \mathrm{M}$ EDTA. The dialyzed solution was applied on a $1.5 \times 22 \mathrm{~cm}$ column of QAESephadex A-50 previously equilibrated with the same buffer. The column was eluted with the starting buffer at a flow rate of $20 \mathrm{ml} / \mathrm{h}$; thrombin was present in fractions not adsorbed to the column. The pooled, concentrated thrombin solution $(3.8 \mathrm{ml})$ was dialyzed against $0.025 \mathrm{M}$ Tris buffer ( $\mathrm{pH} 8.0$ ) containing $0.15 \mathrm{M} \mathrm{NaCl}$ and $0.0001 \mathrm{M}$ EDTA, and filtered through a Sephadex-G150 column $(2.6 \times 100 \mathrm{~cm})$ equilibrated with the same buffer. 3-ml fractions were collected at a flow rate of $30 \mathrm{ml} / \mathrm{h}$. Thrombin emerged at an elution volume of approximately $360 \mathrm{ml}$. The tubes with greatest thrombin-like activity were pooled, concentrated in an Amicon cell fitted with a PM-10 Diaflo membrane, and stored at $-70^{\circ} \mathrm{C}$. Before use, thrombin was assayed upon a substrate of $1.5 \%$ bovine fibrinogen, using Topical thrombin as a standard. The batch used had a specific activity of $500 \mathrm{NIH} \mathrm{U} / \mathrm{mg}$ protein. Although the Amberlite-thrombin has a higher specific activity $(1500 \sim 2500 \mathrm{U} / \mathrm{mg}$ protein), chromatography on QAE-Sephadex and Sephadex G150 was used to separate thrombin from any contaminating Hageman factor. Human or bovine thrombin was appropriately diluted in barbital-saline buffer containing $1 \mathrm{mg} / \mathrm{ml}$

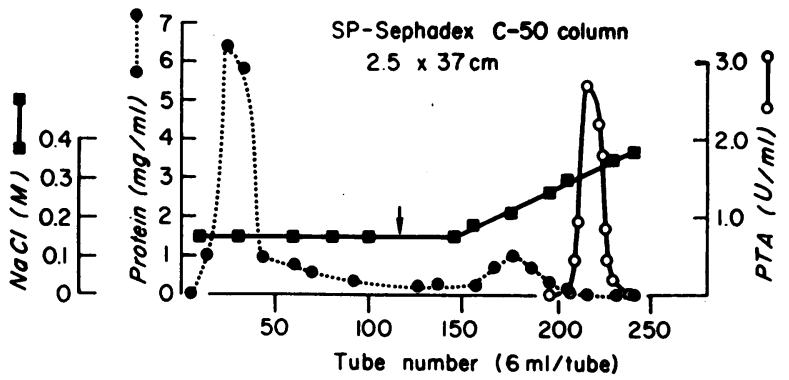

FIGURE 3 The chromatography of PTA on a SP-Sephadex C-50 column. The PTA fraction prepared by the technique demonstrated in Fig. 2 and concentrated as described in the text was applied to the column, which was then eluted first with $0.05 \mathrm{M}$ sodium acetate buffer ( $\mathrm{pH}$ 5.2) containing $0.15 \mathrm{M} \mathrm{NaCl}$ and $0.0001 \mathrm{M}$ EDTA. At the arrow, a linear salt gradient of $500 \mathrm{ml}$ each of the starting buffer and 0.05 $M$ sodium acetate buffer ( $\mathrm{pH} 5.2$ ) containing $0.5 \mathrm{M} \mathrm{NaCl}$ and $0.0001 \mathrm{M}$ EDTA was applied. 
of bovine crystalline albumin (Pentex Biochemical, Kankakee, Ill.) before use.

Bovine trypsin (twice-crystallized, dialyzed salt-free and lyophilized, Worthington Biochemical Corp., Freehold, N. J.) was stored at $4^{\circ} \mathrm{C}$ as a stock solution of $1 \mathrm{mg} / \mathrm{ml}$ in $0.001 \mathrm{M}$ hydrochloric acid.

Streptokinase ("high purity," the gift of Lederle Laboratories, a division of American Cyanamid Co., Pearl River, N. Y.), was dissolved in barbital-saline buffer at a concentration of $20,000 \mathrm{Christensen} \mathrm{U} / \mathrm{ml}$ and stored at $-20^{\circ} \mathrm{C}$.

$\alpha$-Casein (Worthington Biochemical Corp.) was dissolved at a concentration of $1.6 \%(\mathrm{wt} / \mathrm{vol})$ in $0.15 \mathrm{M}$ sodium phosphate buffer ( $\mathrm{pH} 7.5)$.

Partially purified human plasminogen was prepared from human oxalated plasma by a modification of a previously described technique (10). Oxalated plasma was adsorbed with $100 \mathrm{mg}$ of barium sulfate (Merck \& Co., Inc.) per $\mathrm{ml}$ for $15 \mathrm{~min}$ at $37^{\circ} \mathrm{C}$, and the barium sulfate was removed by centrifugation at $16,300 \mathrm{~g}$ for $10 \mathrm{~min}$. The plasma was then diluted with $19 \mathrm{vol}$ of distilled water. A euglobulin fraction was precipitated by adjusting the $\mathrm{pH}$ to 5.2 with $10 \%$ acetic acid. After $2 \mathrm{~h}$ at $4^{\circ} \mathrm{C}$, the precipitate was separated by centrifugation at $16,300 \mathrm{~g}$ for $20 \mathrm{~min}$, dissolved in $0.025 \mathrm{M}$ Tris buffer ( $\mathrm{pH} 8.0$ ) containing $0.15 \mathrm{M}$ sodium chloride, $0.0001 \mathrm{M}$ EDTA, and $0.05 \mathrm{mg}$ Polybrene per $\mathrm{ml}$, and dialyzed against $20 \mathrm{vol}$ of the same buffer overnight. The dialyzed solution was cleared by centrifugation and filtered through a Sephadex G-150 column $(5 \times 87 \mathrm{~cm})$ equilibrated with the same buffer. Approximately $12-14 \mathrm{ml}$ of each sample was applied, and $14 \mathrm{ml}$ fractions were collected at a flow rate of $50 \mathrm{ml} / \mathrm{h}$. The tubes with the greatest caseinolytic activity, detected upon treatment with streptokinase, were pooled and concentrated in an Amicon cell, fitted with a PM-10 Diaflo membrane, to a volume of $74 \mathrm{ml}$. The concentrated plasminogen was dialyzed against $0.025 \mathrm{M}$ Tris buffer containing $0.05 \mathrm{M}$ sodium chloride, $0.0001 \mathrm{M}$ EDTA, and $0.05 \mathrm{mg}$ of Polybrene per $\mathrm{ml}$ and was applied to a $2.5 \times 29 \mathrm{~cm}$ column of QAE-Sephadex A-50 previously equilibrated with the same buffer. The column was washed with $450 \mathrm{ml}$ of the equilibrating buffer and then eluted with a linear salt gradient of $500 \mathrm{ml}$ each of the starting buffer and $0.025 \mathrm{M}$ Tris buffer containing $0.5 \mathrm{M}$ sodium chloride, $0.0001 \mathrm{M}$ EDTA, and $0.05 \mathrm{mg}$ of Polybrene per ml. $6-\mathrm{ml}$ fractions were collected at a flow rate of $20 \mathrm{ml} / \mathrm{h}$. The plasminogen was eluted between 0.11 and $0.18 \mathrm{M}$ sodium chloride and was separated from Hageman factor which was eluted at higher ionic strength. The tubes with greatest streptokinase-activable caseinolytic activity were pooled, precipitated with $60 \%$ ammonium sulfate, and dialyzed against barbital-saline buffer. This preparation had a specific activity of 10 Remmert and Cohen U/mg of protein (11) and had no detectable free plasmin activity. It contained trace amounts of Hageman factor (less than $0.005 \mathrm{U} / \mathrm{ml}$ ) but no measurable PTA, Christmas factor, antihemophilic factor, Stuart factor, factor VII, proaccelerin, prothrombin, thrombin, or fibrinogen.

Streptokinase-activated plasmin was prepared by incubating $18 \mathrm{ml}$ of partially purified human plasminogen $(3.5$ Remmert and Cohen $\mathrm{U} / \mathrm{ml}$ ) with $0.2 \mathrm{ml}$ of streptokinase solution $(20,000 \mathrm{U} / \mathrm{ml})$ in the presence of $0.15 \mathrm{M}$ lysine hydrochloride in $0.15 \mathrm{M}$ sodium phosphate buffer ( $\mathrm{pH} 7.5$ ) for $60 \mathrm{~min}$ at $37^{\circ} \mathrm{C}$. The activated plasmin was stabilized by the addition of one-third volume of $96.2 \%$ glycerol ( J. T. Baker Chemical Co.) and stored at $-20^{\circ} \mathrm{C}$. The preparation contained 3.1 Remmert and Cohen $\mathrm{U} / \mathrm{ml}$ and lysed a $0.6 \%$ bovine fibrin clot in $4 \mathrm{~min}$ at a final concentration of 0.31 Remmert and Cohen $\mathrm{U} / \mathrm{ml}$.
Enzite-trypsin $(0.40 \mathrm{U} / \mathrm{mg})$, Enzite-chymotrypsin $(0.98$ $\mathrm{U} / \mathrm{mg})$, Enzite-papain $(0.35 \mathrm{U} / \mathrm{mg}$ with $5 \mathrm{mM}$ cysteine), Ensite-ficin $(0.10 \mathrm{U} / \mathrm{mg}$ without cystein) and Enzite- $\alpha-$ amylase $(1.8 \mathrm{U} / \mathrm{mg})$, all enzymes in insoluble form, were purchased from Miles Research Div., Miles Laboratories, Inc., Elkhart, Ind. The supporting medium in Enzite- $\alpha$ amylase was microcrystalline cellulose, while that of the other Enzite-enzymes were $O$-(carboxymethyl)cellulose (CM-cellulose). These Enzite-enzymes were rehydrated in distilled water before use and suspended in barbital-saline buffer. Enzite-papain was washed with $0.005 \mathrm{M}$ cysteine and $0.002 \mathrm{M}$ EDTA and resuspended in barbital-saline buffer.

Sepharose-hexanediamine plasmin was prepared from partially purified streptokinase-activated plasmin by attachment to Sepharose 4B-hexadiamine by carbodiimide (12). The Sepharose-hexanediamine-plasmin contained 0.35 Remmert and Cohen $\mathrm{U} / \mathrm{ml}$ of suspension.

Partially purified Hageman factor was prepared from normal human oxalated plasma by tricalcium phosphate adsorption, ammonium sulfate fractionation (20-60\% saturation), and successive column chromatography on QAESephadex A-50, DEAE-Sephadex A-50, Sephadex G150, and SP-Sephadex C-50. ${ }^{2}$ The batch used for the experiment of the effect of trypsin on Hagemen factor had a specific activity of $31 \mathrm{U} / \mathrm{mg}$ of protein (1 $\mathrm{U}$ being that amount found in $1 \mathrm{ml}$ of a standard pool of normal human citrated plasma).

Barium carbonate-activated Hageman factor was prepared by an earlier method (13). $2 \mathrm{ml}$ of partially purified Hageman factor from the Sephadex G-150 step $(10.5 \mathrm{U} / \mathrm{ml}, 3$ $\mathrm{U} / \mathrm{mg}$ protein) was mixed with $60 \mathrm{mg}$ barium carbonate (Merck \& Co., Inc.) in polystyrene tubes at $0^{\circ} \mathrm{C}$ for 10 min. The mixture was centrifuged at $2500 \mathrm{~g}$ for $5 \mathrm{~min}$, and the separated precipitate was washed three times with barbital-saline buffer. The washed precipitate was dissolved in 1 $\mathrm{ml}$ of $1 \mathrm{~N}$ acetic acid and dialyzed against $300 \mathrm{ml}$ of barbital-saline buffer for $3 \mathrm{~h}$.

Partially purified human kallikrein was prepared from pools of approximately $500 \mathrm{ml}$ of normal human-oxalated plasma. Oxalated plasma was adsorbed with $10 \mathrm{mg}$ of tricalcium phosphate $/ \mathrm{ml}$ for $10 \mathrm{~min}$ at $4^{\circ} \mathrm{C}$. The calcium phosphate was removed by centrifugation, Celite $512(20 \mathrm{mg} / \mathrm{ml}$, Johns Manville Products Corp., Celite Div., Denver, Colo.) was added to the plasma, and the mixture was stirred for 10 min. The Celite was separated by filtration on a Buchner funnel, and washed repeatedly with distilled water to remove unabsorbed protein, and then eluted by the repeated addition of small volumes of $0.05 \mathrm{M}$ Tris buffer ( $\mathrm{pH} 8.0$ ) containing $10 \%$ sodium chloride. The eluate, about the same volume as that of the original plasma, was concentrated to approximately $50 \mathrm{ml}$ in an Amicon ultrafiltration cell using PM-10 Diaflo membrane and was dialyzed against 2 liters of 0.15 $\mathrm{M}$ sodium acetate buffer ( $\mathrm{pH} 5.2$ ). The dialyzed eluate was applied to a column of CM-Sephadex C-50 $(2.5 \times 30 \mathrm{~cm}$ Pharmacia Fine Chemicals Inc.) equilibrated with $0.15 \mathrm{M}$ sodium acetate buffer $(\mathrm{pH}$ 5.2). After the column was washed with approximately $120 \mathrm{ml}$ of $0.067 \mathrm{M}$ sodium phosphate buffer ( $\mathrm{pH} \mathrm{6.0)}$, a linear gradient of $500 \mathrm{ml}$ each of $0.067 \mathrm{M}$ sodium phosphate buffer ( $\mathrm{pH} 6.0$ ) and the same buffer in $0.5 \mathrm{M}$ sodium chloride was started, and approximately 5-ml fractions were collected. After approximately 50 tubes, two peaks of TAME-esterase activity were eluted: the first contained very little activated PTA activity, whereas the second had most of the activated PTA activity. The first TAME-esterase peak was concentrated

\footnotetext{
${ }^{2}$ Saito, H., and O. D. Ratnoff, unpublished data.
} 
in an Amicon cell, fitted with a PM-10 Diaflo membrane, and dialyzed against $0.025 \mathrm{M}$ Tris buffer ( $\mathrm{pH}$ 8.0) containing $0.0001 \mathrm{M}$ EDTA. The dialyzed solution (approximately $63 \mathrm{ml}$ ) was applied to a column of QAE-Sephadex A-50 $(2.5 \times 32 \mathrm{~cm})$ previously equilibrated with that same buffer. The column was eluted with the starting buffer, and material possessing TAME-esterase activity, which was present in those fractions which did not adhere to the column, was concentrated to approximately $100 \mathrm{ml}$ in an Amicon cell using PM-10 membrane. This preparation released $1.1 \mu \mathrm{M}$ methanol $/ \mathrm{ml}$ per $\mathrm{h}$ in the TAME-esterase assay (specific activity: $60 \mu \mathrm{M} / \mathrm{mg}$ protein per $\mathrm{h}$ ) and, on the average, $120 \mathrm{ng}$ of bradykinin in the rat uterus assay. It contained trace amount of activated PTA activity (less than $0.01 \mathrm{U} / \mathrm{ml}$ ) and Hageman factor cofactor but no measurable amount of Hageman factor, Christmas factor, thrombin, plasmin, and plasminogen.

Partially purified $C \overline{1}$ (an esterase derived from the first component of complement) was prepared by a method described earlier (14). The preparation formed a single band on analytic disc gel electrophoresis and was free of any measurable amount of any of the known clotting factors. It contained $8.6 \mathrm{U} / \mathrm{ml}$, as tested upon a substrate of $N$ acetyl-L-tyrosine ethyl ester (15). $1 \mathrm{U}$ is that amount which leads to the release of $0.5 \mu \mathrm{eq}$ of acid in $15 \mathrm{~min}$ under the conditions used.

Rabbit brain tissue thromboplastin (Bacto Thromboplastin, Difco Laboratories, Detroit, Mich.) and human brain tissue thromboplastin (Cappel Lab., Wayne, Pa.) were suspended in barbital-saline buffer at a concentration of 2 $\mathrm{mg} / \mathrm{ml}$ and washed three times by centrifugation in a Beckman model $\mathrm{L}$ ultracentrifuge (Beckman Instruments, Inc., Fullerton, Calif.), using a SW 39L rotor at $130,000 \mathrm{~g}$ for $60 \mathrm{~min}$ at $4^{\circ} \mathrm{C}$. Human placental tissue thromboplastin (purified and relipidated) and crude human brain tissue thromboplastin, the generous gift of Dr. F. Pitlick, Department of Medicine, Yale University, were suspended in $0.05 \mathrm{M}$ imidazole-saline buffer ( $\mathrm{pH}$ 6.8) and washed once by ultracentrifugation as described above.

Lima bean trypsin inhibitor (LBTI, Worthington Biochemical Corp.) was dissolved in barbital-saline buffer at a concentration of $1 \mathrm{mg} / \mathrm{ml}$, and hirudin (4080 ATE U/mg protein, Veb Arzneimittelwerk Dresden, East Germany) was dissolved in barbital-saline at a concentration of 1500 ATE $\mathrm{U} / \mathrm{ml}$ and frozen at $-70^{\circ} \mathrm{C}$.

Rabbit antiserums to human Hageman factor and to human-activated PTA were prepared and treated as reported earlier (16). Undiluted anti-Hageman factor antiserum inhibited $95 \%$ of Hageman factor in an equal volume of normal human plasma when incubated for $1 \mathrm{~h}$ at $37^{\circ} \mathrm{C}$, and formed a single line upon immunodiffusion in $0.9 \%$ agarose against pooled normal plasma. The anti-PTA-serum, diluted 16-fold, inactivated $90 \%$ of the PTA of an equal volume of pooled normal plasma in $1 \mathrm{~h}$ at $37^{\circ} \mathrm{C}$ and formed a single line upon immunodiffusion against concentrated partially purified activated human PTA.

Goat antiserum to human IgG was obtained from Hyland Div., Travenol Laboratories, Inc., Costa Mesa, Calif. This antiserum formed a single precipitin line on immunoelectrophoresis in $0.9 \%$ agarose $(0.05 \mathrm{M}$ barbital buffer, $\mathrm{pH} 8.6$ $10 \mathrm{vol} / \mathrm{cm}, 60 \mathrm{~min}$ ) against normal human plasma and purified human IgG (Calbiochem, San Diego, Calif.).

Crude kininogen for the assay of kallikrein-like activity was prepared by incubating normal human plasma, kept from contact with glass, at $61^{\circ} \mathrm{C}$ for $60 \mathrm{~min}$ to destroy its content of Hageman factor and plasma prekallikrein; the plasma was centrifuged, and the supernatant fluid was stored in polyethylene containers at $-20^{\circ} \mathrm{C}$.

Bradykinin, the gift of Sandoz, Inc., Hanover, N. J., was dissolved at a concentration of $1 \mu \mathrm{g} / \mathrm{ml}$ in $0.15 \mathrm{M}$ sodium chloride solution and stored at $-20^{\circ} \mathrm{C}$ in cellulose nitrate tubes. Before use, it was diluted appropriately in similar tubes.

$O$-phenanthroline (Fisher Scientific Co., Inc., Pittsburgh, $\mathrm{Pa}$.) was dissolved at a concentration of $0.01 \mathrm{M}$ in barbitalsaline buffer and stored at $4^{\circ} \mathrm{C}$.

Gliddex- $P$, a crude preparation of soybean phosphatides (the gift of the Glidden Paint Co., Chicago, Ill.) was prepared as a $0.1 \%$ suspension in $0.15 \mathrm{M}$ sodium chloride solution and stored at $-20^{\circ} \mathrm{C}$ until needed.

Kaolin (acid-washed, N.F., Fisher Scientific Co., Inc.), chiefly aluminum hydrate, was suspended in the appropriate buffer with the aid of a mechanical homogenizer. KaolinGliddex, used to measure the concentration of clotting factors in the intrinsic pathway of thrombin formation, was a mixture of $50 \mathrm{mg}$ of kaolin suspended in $5 \mathrm{ml}$ of $0.1 \%$ Gliddex-P

Barbital-saline buffer was $0.025 \mathrm{M}$ barbital in $0.125 \mathrm{M}$ sodium chloride ( $\mathrm{pH} 7.5)$.

Carboxymethylcellulose (CM-cellulose) was obtained in microgranular, preswollen form from $H$. Reeve Angel \& Co., Inc., Clifton, N. J., and Sepharose $4 B$ was purchased from Pharmacia Fine Chemicals, Inc.

Silicone-coated glassware, including chromatographic columns, or plastic apparatus was used unless otherwise noted. The glassware was coated with silicone (Dri-Film SC-87, Pierce Chemical Co., Rockford, Ill.) and rinsed thoroughly with tap water and then distilled water, and the water was evaporated before use.

\section{METHODS}

Assay of PTA was performed by a reported method (3). In essence, the sample was diluted appropriately in barbitalsaline buffer usually more than 20 times, since the presence of Polybrene $(0.05 \mathrm{mg} / \mathrm{ml})$ in some PTA preparations did not interfere with the assay of PTA at a $1: 20$ dilution, and was incubated with kaolin-Gliddex and a substrate of human or bovine PTA-deficient plasma for $8 \mathrm{~min}$ at $37^{\circ} \mathrm{C}$ in $10 \times 75-\mathrm{mm}$ glass tubes. The mixture was then recalcified, and the clotting time was measured at $37^{\circ} \mathrm{C}$. The clotting time was converted to arbitrary units by comparison with the clotting activity of serial dilutions of a standard pool of plasma. A linear relationship existed between the clotting time and the concentration of PTA when plotted on full logarithmic paper. When PTA in highly purified preparations was assayed, the samples were diluted in $0.1 \%$ bovine serum albumin (Armour Pharmaceutical Company, Chicago, III.) in barbital-saline buffer.

Assay of activated PTA was performed by incubating suitably diluted sample with Gliddex and human or bovine PTA-deficient plasma in $10 \times 75-\mathrm{mm}$ polystyrene tubes at $37^{\circ} \mathrm{C}$ for $1 \mathrm{~min}(3)$. The contents were immediately recalcified, and the clotting time was measured at $37^{\circ} \mathrm{C}$. In many experiments, the results were expressed as the clotting time and as the per cent of the activated PTA activity relative to that of the sample with the greatest activity.

Assays for Hageman factor, Christmas factor, antihemophilic factor, Stuart factor, factor VII, proaccelerin, pro-

${ }^{3}$ This preparation can now be obtained from the Central Soya Co., Inc., Fort Wayne, Ind. 
thrombin, thrombin, and fibrinogen were performed by techniques referred to earlier (17). Plasminogen and plasmin were assayed by caseinolytic activity with and without streptokinase by a modification of the method of Remmert and Cohen (11).

Hageman factor-cofactor was assayed by a method previously described (18).

The fibrinolytic activity of partially purified PTA was restimated by mixing $0.1 \mathrm{ml}$ of PTA $(2 \mathrm{U} / \mathrm{ml})$ with 0.025 $\mathrm{ml}$ of streptokinase $(20,000$ Christensen $\mathrm{U} / \mathrm{ml}), 0.2 \mathrm{ml}$ of $1.5 \%$ bovine fibrinogen solution and $0.1 \mathrm{ml}$ of partially purified bovine thrombin $(40 \mathrm{NIH} \mathrm{U} / \mathrm{ml})$ in $10 \times 75-\mathrm{mm}$ polystyrene tubes. The resultant clots were incubated at $37^{\circ} \mathrm{C}$ and inspected for fibrinolysis.

The presence of $\operatorname{Ig} G$ was tested by immunodiffusion in $0.9 \%$ agarose gel against goat antiserum to human IgG for 2 days at room temperature.

$T A M E$-esterase activity was measured by a minor modification of Siegelman's method (Siegelman, Carlson, and Robertson 19). A sample of $0.25 \mathrm{ml}$ was incubated at $37^{\circ} \mathrm{C}$ with $2.5 \mathrm{ml}$ of $0.015 \mathrm{M}$ TAME in $0.067 \mathrm{M}$ sodium phosphate buffer $(\mathrm{pH} 7.5)$ containing $0.6 \% \mathrm{NaCl}$. After 1 and $61 \mathrm{~min}, 1-\mathrm{ml}$ aliquots were withdrawn and transferred to glass tubes containing $0.5 \mathrm{ml}$ of $0.75 \mathrm{M}$ perchloric acid. In succession, $0.1 \mathrm{ml}$ of a $2 \%$ aqueous potassium-permanganate solution, $0.1 \mathrm{ml}$ of $10 \%$ aqueous sodium bisulfite solution, and $4.0 \mathrm{ml}$ of chromatropic acid "working reagent" were added to the assay tubes. The color evolved after heating the tubes in a boiling water bath for $15 \mathrm{~min}$ was measured at $580 \mathrm{~nm}$. The color was compared with that of a freshly prepared standard of methanol in phosphate-saline buffer, assayed in the same way. The results were expressed as micromoles of methanol released/milliliter per hour.

Kallikrein-like activity was estimated by incubating a mixture of $0.1 \mathrm{ml}$ of $0.01 \mathrm{M} O$-phenanthroline solution, 0.1 $\mathrm{ml}$ of crude kininogen, $0.1-0.6 \mathrm{ml}$ of sample to be tested, and sufficient barbital-saline buffer to bring the volume to $1.0 \mathrm{ml}$ in polystyrene tubes for $15 \mathrm{~min}$ at $37^{\circ} \mathrm{C}$. The effect of portions of this mixture was then tested on the estrus rat uterus in comparison with a bradykinin standard as described earlier (20).

The activation of $P T A$ by trypsin was studied by the following methods. After $0.1 \mathrm{ml}$ of PTA $(1.7 \mathrm{U} / \mathrm{ml})$ and $0.1 \mathrm{ml}$ of trypsin $(0.1 \mathrm{mg} / \mathrm{ml})$ were incubated at $37^{\circ} \mathrm{C}$, the trypsin was inhibited by the addition of $0.1 \mathrm{ml}$ of LBTI $(0.33 \mathrm{mg} / \mathrm{ml})$. The mixture was then assayed on substrates of PTA-deficient or Christmas factor-deficient plasma; 0.1 $\mathrm{ml}$ of the solution to be tested, $0.1 \mathrm{ml}$ of Gliddex-P and 0.1 $\mathrm{ml}$ substrate plasma were mixed in a $10 \times 75 \mathrm{~mm}$ polystyrene tube, and after incubation for $1 \mathrm{~min}$ at $37^{\circ} \mathrm{C}, 0.1$ $\mathrm{ml}$ of $0.025 \mathrm{M} \mathrm{CaCl}_{2}$ was added and the clotting time was measured. The concentration of LBTI used was sufficient to inhibit tryptic activity, but did not interfere with the clotting assay for activated PTA. The effect of varying the concentration of trypsin on PTA activation was studied by incubating different amounts of trypsin with a constant amount of PTA. At intervals, portions of this mixture were removed, and LBTI was added, and the mixture tested for activated PTA. The effect of varying the concentration of PTA on PTA activation was investigated by incubating different amounts of PTA with a constant quantity of trypsin. After inhibition of the trypsin with LBTI activated PTA was assayed.

The effect of insolubilized enzymes on PTA was studied by incubating $0.3 \mathrm{ml}$ of partially purified PTA and $0.2 \mathrm{ml}$ of a suspension of a water-insoluble enzyme (Sepharoseplasmin, Enzite-trypsin, Enzite-chymotrypsin, Enzite-papain,
Enzite-ficin, or Enzite-amylase) in a $10 \times 7 \overline{5} \mathrm{~mm}$ polystyrene tube at $37^{\circ} \mathrm{C}$, with the occasional stirring. At intervals, the tubes were centrifuged at $800 \mathrm{~g}$ for $5 \mathrm{~min}$ at $2^{\circ} \mathrm{C}$, and the supernatant fluid was separated from the precipitated enzyme, using a silicone-coated glass dropper. The supernatant fluid was immediately tested on PTA-deficient, Hageman factor-deficient, or Christmas factor-deficient plasma, as described above.

The effect of trypsin on the clot-promoting property of Hageman factor was studied by incubating equal volumes of partially purified Hageman factor $(0.4 \mathrm{U} / \mathrm{ml})$ and trypsin $(0.05 \mathrm{mg} / \mathrm{ml})$ at $37^{\circ} \mathrm{C}$. At intervals, portions were tested for both Hageman factor and activated Hageman factor activity after inhibiting trypsin by LBTI. Assay of activated Hageman factor was performed by incubating sample with Gliddex and Hageman factor-deficient plasma in $10 \times 75 \mathrm{~mm}$ polystyrene tubes at $37^{\circ} \mathrm{C}$ for $8 \mathrm{~min}$. The contents were then recalcified, and the clotting time was measured at $37^{\circ} \mathrm{C}$.

The effect of temperature on PTA activation by trypsin was studied as follows: $0.1 \mathrm{ml}$ of PTA $(1.7 \mathrm{U} / \mathrm{ml})$ and $0.1 \mathrm{ml}$ of trypsin $(0.1 \mathrm{mg} / \mathrm{ml})$ were incubated for $10 \mathrm{mith}$ at varying temperatures, after which the action of trypsin was stopped by adding $0.1 \mathrm{ml}$ of LBTI $(0.33 \mathrm{mg} / \mathrm{ml})$. The mixtures were then assayed for activated PTA-like activity. A standard curve was prepared by testing serial dilution of the mixture incubated at $37^{\circ} \mathrm{C}$. The results were expressed as the per cent of PTA-like activity generated relative to that evolving at $37^{\circ} \mathrm{C}(100 \%)$.

The effect of specific rabbit antiserums upon trypsinactivated PT A-like activity was tested by incubating $0.1 \mathrm{ml}$ of Enzite-trypsin- or soluble trypsin-activated PTA with $0.1 \mathrm{ml}$ of absorbed, treated antiserum, against PTA, Hageman factor, or similarly treated normal rabbit serum for $30 \mathrm{~min}$ at $37^{\circ} \mathrm{C}$ in $10 \times 75-\mathrm{mm}$ polystyrene tubes. A $0.1 \mathrm{ml}$ aliquot was then tested for activated PTA-like activity by the method described above. A standard curve was made by testing serial dilution of trypsin-activated PTA incubated with normal rabbit serum in $0.1 \%$ bovine albumin in barbital-saline buffer.

The effect of thrombin on PTA was studied by incubating equal volumes of PTA $(2 \mathrm{U} / \mathrm{ml})$ and human thrombin $(1.2$ $\mathrm{U} / \mathrm{ml})$ or partially purified bovine thrombin $(2 \mathrm{U} / \mathrm{ml})$ in $10 \times 75-\mathrm{mm}$ polystyrene tubes at $37^{\circ} \mathrm{C}$. At intervals, portions were tested for activated PTA activity after inhibiting thrombin by hirudin equivalent to the thrombin used.

The effect of plasma kallikrein on PTA was studied by incubating equal volumes of PTA $(2 \mathrm{U} / \mathrm{ml})$ and kallikrein (1.1 $\mu \mathrm{M}$ methanol released $/ \mathrm{ml}$ per $\mathrm{h}$ ) at $37^{\circ} \mathrm{C}$ in $10 \times 75$ $\mathrm{mm}$ polystyrene tubes. At intervals, portions were tested for activated PTA activity using bovine PTA-deficient plasma as the substrate. As a control, PTA was incubated with trypsin $(0.1 \mathrm{mg} / \mathrm{ml})$ and was tested in the same way after inhibition of trypsin with LBTI $(0.33 \mathrm{mg} / \mathrm{ml})$.

The effect of $C \overline{1}$ on PTA was studied by incubating equal volumes of PTA $(1.7 \mathrm{U} / \mathrm{ml})$ and $\mathrm{C}^{\overline{1}}(8.6 \mathrm{U} / \mathrm{ml})$ at $37^{\circ} \mathrm{C}$. At intervals, portions were tested for activated PTA activity, using human PTA-deficient plasma as the substrate. In preliminary experiments, it was found that this amount of $\bar{C} \overline{1}$ did not interfere with the assay for activated PTA. Therefore, no inhibitor was used to stop $\mathrm{C} \dot{1}$ activity after incubation with PTA.

The effect of tissue thromboplastin on PT.A was studied by incubating $5 \mathrm{ml}$ of partially purified PTA $(1 \mathrm{U} / \mathrm{ml})$ or barbital-saline buffer at $37^{\circ} \mathrm{C}$ for $20 \mathrm{~min}$ with $1 \mathrm{mg} / \mathrm{ml}$ of rabbit or human brain tissue thromboplastin, previously washed with barbital-saline buffer. The tissue thrombo- 
plastin was then sedimented by ultracentrifugation at 130 ,$000 \mathrm{~g}$ for $2 \mathrm{~h}$ at $2^{\circ} \mathrm{C}$. The clear supernate was removed and tested for activated PTA-like activity. In experiments using purified human placental tissue thromboplastin and crude human brain tissue thromboplastin obtained from $\mathrm{Dr}$. F. Pitlick, PTA was incubated with these thromboplastins in imidazole-saline buffer $(\mathrm{pH} 6.8)$ for $90 \mathrm{~min}$ at $37^{\circ} \mathrm{C}$.

A crude estimation of molecular weight of unactivated PTA, Hageman factor-activated PTA, and trypsin-activated PTA was obtained by applying $3 \mathrm{ml}$ of sample in $1 \%$ bovine albumin (the latter used as an internal marker) to a $2.6 \times$ $100 \mathrm{~cm}$ column of Sephadex G-150 equilibrated with $0.025 \mathrm{M}$ Tris- $\mathrm{HCl}$ buffer $\left(\mathrm{pH} 8.0\right.$ at $4^{\circ} \mathrm{C}$ ) containing $0.15 \mathrm{M} \mathrm{NaCl}$ and $0.0001 \mathrm{M}$ EDTA. The column was eluted with the same buffer at the flow rate of $10-15 \mathrm{ml} / \mathrm{h}$, and $3 \mathrm{ml}$-fractions were collected. Fractions were tested for PTA and activated PTA activity. As markers, Blue dextran 2000 (Pharmacia Fine Chemicals, Inc.) and the following proteins were used: $1 \%$ bovine gamma globulin (Armour Pharmaceutical Company, mol wt 160,000 ), $1 \%$ rabbit muscle aldolase (Worthington Biochemical Corp., mol wt 158,000), $1 \%$ yeast alcohol dehydrogenase (Worthington Biochemical Corp., mol wt 151,000$), 0.1 \mathrm{ml} / \mathrm{ml}$ of Escherichia coli alkaline phosphatase (Worthington Biochemical Corp., mol wt 80,000 ), $1 \%$ bovine albumin (Armour Pharmaceutical Co., mol wt 67,000), 1\% ovalbumin (Schwarz/Mann Div., Becton, Dickinson \& Co., Orangeburg, N. Y., mol wt 45,000). The peak of maximal elution of these markers were read at OD $280 \mathrm{~nm}$ except for alkaline phosphatase, which was assayed on a substrate of disodium $p$-nitrophenyl phosphate (ICN Nutritional Biochemicals Div.) (21). The molecular weight of PTA and activated PTA were estimated by using Andrews' assumption that a linear relationship exists between the logarithm of molecular weight and elution volume (22). A regression line was drawn, using the method of least squares and the molecular weights of PTA and activated PTA were read by extrapolation. This estimation makes the unproved assumption that the molecules tested are spheroidal.

Protein was determined by the method of Lowry, Rosebrough, Farr, and Randall (23) and was estimated more crudely by absorption at $280 \mathrm{~nm}$ using a Beckman model DU Spectrophotometer.
Dialyses were performed at $4^{\circ} \mathrm{C}$ in cellophane casings (VisKing Corp., Chicago, Ill.) prepared by boiling in 0.0001 $M$ EDTA, followed by thorough washing in distilled water. Centrifugations were carried out at $2^{\circ} \mathrm{C}$ in an International PR-2 refrigerated centrifuge (International Equipment Co., Boston, Mass.) and at high speeds in a Servall $\mathrm{RC}-2$ refrigerated centrifuge unless otherwise noted.

\section{RESULTS}

PT $A$ activation by trypsin. When partially purified unactivated PTA was first incubated with trypsin and tryptic action was then inhibited by LBTI, a clot-promoting agent was found which shortened the clotting time of PTA-deficient plasma, but not that of Christmas factor-deficient plasma (Table I). No such activity was found when trypsin was inhibited by LBTI before its addition to PTA, or when PTA alone was incubated. The generation of a clot-promoting agent from PTA by trypsin was confirmed by an alternative method in which the insolubilized trypsin was used. Incubation of PTA with Enzite-trypsin resulted in the time-dependent generation of an agent that shortened the clotting time of PTA-deficient or Hageman factor-deficient plasma but not that of Christmas factor-deficient plasma. On the contrary, the incubation of either PTA, Enzitetrypsin alone, or PTA with CM-cellulose did not induce this property (Table II). These data suggest that activated PTA-like activity was generated from precursor PTA by the action of trypsin. Since the same results were obtained with either human or bovine PTA-deficient plasma as substrate in the activated PTA assay, bovine PTA-deficient plasma was used in most of the following studies.

The way in which trypsin converts PTA to its activated form was investigated by varying the concentration of either trypsin or PTA and studying the effect of

TABLE I

PTA Activation by Trypsin and Its Inhibition by LBTI

\begin{tabular}{|c|c|c|c|c|}
\hline \multicolumn{3}{|c|}{ Generation mixtures } & \multicolumn{2}{|c|}{ Clotting time of substrate plasma } \\
\hline 1st incubation & Addition & $\begin{array}{c}\text { 2nd } \\
\text { incubation }\end{array}$ & PTA deficient & $\begin{array}{l}\text { Christmas } \\
\text { factor def. }\end{array}$ \\
\hline & & & $s$ & $s$ \\
\hline $\mathrm{PTA}+$ Trypsin, $37^{\circ} \mathrm{C} 10 \mathrm{~min}$ & LBTI & $0^{\circ} \mathrm{C} 3 \mathrm{~min}$ & $60.9(100 \%)^{*}$ & $>400$ \\
\hline PTA + Buffer, $\quad 37^{\circ} \mathrm{C} 10 \mathrm{~min}$ & Buffer & $0^{\circ} \mathrm{C} 3 \mathrm{~min}$ & $358.6(<1 \%)^{*}$ & $>400$ \\
\hline LBTI + Trypsin, $\quad 0^{\circ} \mathrm{C} \quad 3 \mathrm{~min}$ & PTA & $37^{\circ} \mathrm{C} 10 \mathrm{~min}$ & $232.6(<1 \%)^{*}$ & $>400$ \\
\hline LBTI + Trypsin, $\quad 0^{\circ} \mathrm{C} \quad 3 \mathrm{~min}$ & Buffer & $37^{\circ} \mathrm{C} 10 \mathrm{~min}$ & $>400(<1 \%)^{*}$ & $>400$ \\
\hline
\end{tabular}

$0.1 \mathrm{ml}$ each of PTA $(1.7 \mathrm{U} / \mathrm{ml})$, trypsin $(0.1 \mathrm{mg} / \mathrm{ml})$, and LBTI $(0.33 \mathrm{mg} / \mathrm{ml})$ were added and incubated in the sequence shown above in $10 \times 75-\mathrm{mm}$ polystyrene tubes. $0.1-\mathrm{ml}$ aliquots of mixtures were then assayed on substrates of PTA-deficient plasma or Christmas factor-deficient plasma as described in Methods.

* Expressed as the percent of the clot-promoting activity relative to that of the sample with the greatest activity. 
TABLE II

PT.1 Actiration by Insolubilized Trypsin

\begin{tabular}{|c|c|c|c|c|c|}
\hline \multirow[b]{2}{*}{ Agent tested } & \multirow[b]{2}{*}{ PTA } & \multirow[b]{2}{*}{ Time at $37^{\circ} \mathrm{C}$} & \multicolumn{3}{|c|}{ Clotting time of substrate plasma } \\
\hline & & & PTA def. & $\begin{array}{c}\text { Hageman } \\
\text { factor def. }\end{array}$ & $\begin{array}{l}\text { Christmas } \\
\text { factor def. }\end{array}$ \\
\hline & & $\min$ & & $s$ & \\
\hline None & + & 20 & 280.0 & $>300$ & $>300$ \\
\hline Enzite-trypsin $4 \mathrm{mg} / \mathrm{ml}$ & + & 5 & 125.4 & 151.3 & $>300$ \\
\hline Enzite-trypsin $4 \mathrm{mg} / \mathrm{ml}$ & + & 10 & 98.5 & 104.6 & $>300$ \\
\hline Enzite-trypsin $4 \mathrm{mg} / \mathrm{ml}$ & + & 20 & 69.8 & 75.2 & $>300$ \\
\hline Enzite-trypsin $4 \mathrm{mg} / \mathrm{ml}$ & - & 20 & $>300$ & $>300$ & $>300$ \\
\hline CM-cellulose $4 \mathrm{mg} / \mathrm{ml}$ & + & 20 & 282.0 & $>300$ & $>300$ \\
\hline
\end{tabular}

Mixtures of $0.3 \mathrm{ml}$ PTA $(2.4 \mathrm{U} / \mathrm{ml})$ and $0.2 \mathrm{ml}$ of each agent or barbital-saline buffer were incubated at $37^{\circ} \mathrm{C}$ with the occasional stirring for the time indicated and then centrifuged at $800 \mathrm{~g}$. for $5 \mathrm{~min}$ at $2^{\circ} \mathrm{C}$. The supernatant fluid was removed with silicone-coated glass droppers and immediately tested on bovine PTA-deficient plasma, Hageman factor-deficient plasma or Christmas factor-deficient plasma as described in Methods.

these maneuvers on the evolution of activated PTA-like activity. When the concentration of trypsin was varied over a fourfold range and the concentration of PTA was kept constant, the yield of clot-promoting activity (presumably due to activated PTA-like) was essentially the same (Fig. 4). On the other hand, when the concentration of PTA was varied over a 13-fold range and that of trypsin was kept constant, the yield varied in proportion to the initial concentration of PTA (Fig. $5)$. These data suggest that trypsin generates clot-promoting activity from PTA enzymatically. When partially purified, unactivated Hageman factor was incubated with trypsin under the same conditions and was

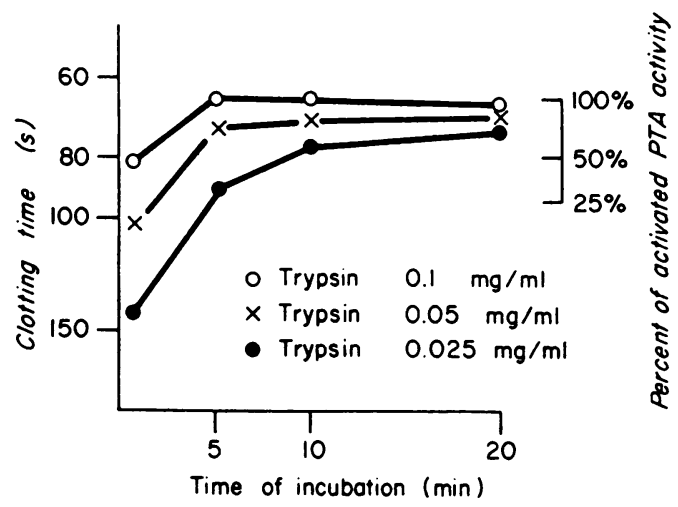

FIGURE 4 The effect of varying the concentration of trypsin upon the PTA activation by trypsin. $0.3 \mathrm{ml}$ of PTA (2.4 $\mathrm{U} / \mathrm{ml})$ and $0.3 \mathrm{ml}$ of trypsin $(0.1,0.05$, or $0.025 \mathrm{mg} / \mathrm{ml})$ were incubated at $37^{\circ} \mathrm{C}$ in $10 \times 75-\mathrm{mm}$ polystyrene tubes. At intervals, portions of this mixture were removed and the tryptic action was stopped by the addition of LBTI. The mixture was then tested for activated PTA, using bovine PTA-deficient plasma as a substrate. tested on Hageman factor-deficient plasma, no significant clot-promoting activity was generated. The clotpromoting activity of the Hageman factor preparation evolved upon contact with glass decayed during its incubation with trypsin, a result consistent with that reported by Soltay, Movat, and Özge-Anwar (24). These data suggest that clot-promoting activity was evolved from PTA by trypsin enzymatically and that this PTA activation was not via Hageman factor activation. As discussed in a previous paper (3), no valid comparison can be made between the assay for PTA and activated PTA. Were the assumption made that such a comparison was possible, approximately all the PTA was converted into its active form by trypsin.

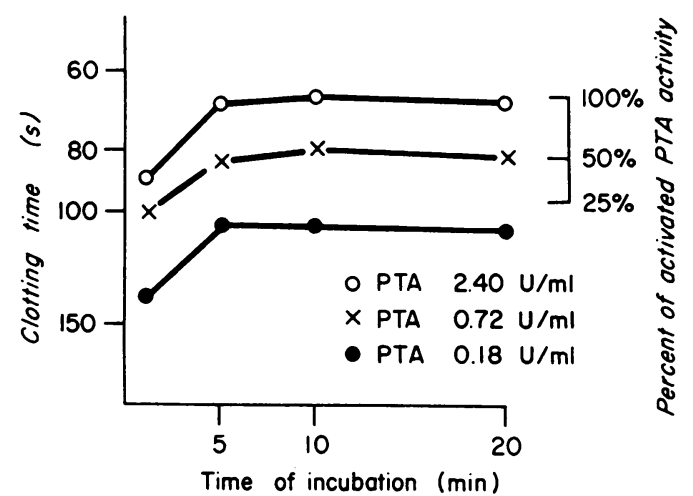

FIGURE 5 The effect of varying the concentration of PTA upon the PTA activation by trypsin. $0.3 \mathrm{ml}$ of PTA (2.4, 0.72 , or $0.18 \mathrm{U} / \mathrm{ml})$ and $0.3 \mathrm{ml}$ of trypsin $(0.1 \mathrm{mg} / \mathrm{ml})$ were incubated at $37^{\circ} \mathrm{C}$ in $10 \times 75-\mathrm{mm}$ polystyrene tubes. At intervals, portions of this mixture were removed and the tryptic action was stopped by the addition of LBTI. The mixture was then tested for activated PTA, using bovine PTA-deficient plasma as a substrate. 
TABLE III

Effect of Temperature on PTA Activation by Trypsin

\begin{tabular}{ccc}
\hline Incubation temperature & \multicolumn{2}{c}{ Clotting time of substrate plasma } \\
\hline & $s$ & $\%$ \\
$0^{\circ} \mathrm{C}$ & 105.7 & 10 \\
$10^{\circ} \mathrm{C}$ & 90.3 & 20 \\
$25^{\circ} \mathrm{C}$ & 85.1 & 25 \\
$37^{\circ} \mathrm{C}$ & 62.0 & 100 \\
\hline
\end{tabular}

$0.1 \mathrm{ml}$ of PTA $(1.7 \mathrm{U} / \mathrm{ml})$ and $0.1 \mathrm{ml}$ of trypsin $(0.1 \mathrm{mg} / \mathrm{ml})$ were incubated for $10 \mathrm{~min}$ at varying temperature. The trypsin was inhibited by the addition of $0.1 \mathrm{ml}$ of LBTI $(0.33$ $\mathrm{mg} / \mathrm{ml}$ ) and portions were assayed for activated PTA-like activity, using bovine PTA-deficient plasma as substrate, as described in Methods. The results were expressed as the clotting time and as the percent of activated PTA-like activity generated relative to that evolving at $37^{\circ} \mathrm{C}(100 \%)$.

Effect of temperature upon the PTA activation by trypsin. The rate at which activated PTA-like activity generated in a mixture of PTA and trypsin was temperature dependent (Table III). For example, when PTA was incubated for $10 \mathrm{~min}$ with trypsin at $37^{\circ} \mathrm{C}$, a portion clotted PTA-deficient plasma in $62.0 \mathrm{~s}$, whereas when PTA and trypsin were kept at $0^{\circ} \mathrm{C}$, the clotting time was $105.7 \mathrm{~s}$.

Effect of specific antiserums upon trypsin-activated PTA-like activity. The trypsin-activated PTA was incubated with antiserums directed against Hageman factor, activated PTA or an analogous fraction of normal rabbit serum (Table IV). The clot-promoting activity formed from PTA by trypsin was abolished by the incubation with the antiserum against activated PTA but not that against Hageman factor. The same data were obtained when PTA was activated by Enzitetrypsin. These data support the view that the clotpromoting agent evolved is activated PTA.

Test for autoactivation of PTA. The possibility that PTA might become active autocatalytically was investigated by incubating unactivated PTA with Enzitetrypsin-activated PTA at $25^{\circ} \mathrm{C}$. No autoactivation was detectable during $180 \mathrm{~min}$ of incubation. When Enzitetrypsin was added after $180 \mathrm{~min}$, further activated PTA activity was generated, indicating that lack of autoactivation was not due to the spontaneous deterioration of PTA during incubation. These results are compatible with earlier experiments by Ratnoff, Davie, and Mallett (1).

Effect of other enzymes on PTA. The activation of PTA by trypsin suggested that other proteases might effect PTA. Several enzymes including human and bovine thrombin, plasma kallikrein, $C \overline{1}$, Enzite-chymotrypsin, Enzite-papain, Enzite-ficin, Sepharose-plasmin, and Enzite-amylase, were tested for their ability to activate PTA. None of these was effective. When Amberlite-thrombin prepared from bovine topical thrombin was first incubated with PTA and thrombin was then neutralized by hirudin, a clot-promoting agent was found which shortened the clotting time of PTA-deficient or Hageman factor-deficient plasma, but not that of Christmas factor-deficient plasma. However, this activated PTA-like activity did not evolve when human thrombin was used or Amberlite-thrombin was further purified by chromatography on QAE-Sephadex A-50

TABLE IV

Effect of Specific Antiserums on the Trypsin-Activated PTA-Like Activity

\begin{tabular}{lccc}
\hline \multicolumn{1}{c}{ Addition } & Trypsin-activated PTA & \multicolumn{2}{c}{ Clotting time of substrate } \\
\hline & & $s$ & $\%$ \\
Normal rabbit serum, undiluted & + & 52.0 & 100 \\
Normal rabbit serum, undiluted & - & $>500$ & \\
PTA antiserum, undiluted & + & 482.7 & $<1$ \\
PTA antiserum, $\frac{1}{2}$ diluted & + & 190.7 & $<1$ \\
PTA antiserum, $\frac{1}{4}$ diluted & + & 162.4 & $<1$ \\
PTA antiserum, $\frac{1}{8}$ diluted & + & 112.5 & 2 \\
PTA antiserum, undiluted & - & $>500$ & \\
Hageman factor antiserum, undiluted & + & 53.7 & 95 \\
Hageman factor antiserum, undiluted & - & $>500$ & \\
\hline
\end{tabular}

$0.3 \mathrm{ml}$ of PTA $(4 \mathrm{U} / \mathrm{ml})$ and $0.3 \mathrm{ml}$ of trypsin $(0.1 \mathrm{mg} / \mathrm{ml})$ were incubated at $37^{\circ} \mathrm{C}$ for 10 min, and trypsin was inhibited by the addition of $0.3 \mathrm{ml}$ of LBTI $(0.5 \mathrm{mg} / \mathrm{ml})$. The mixture was then incubated with equal volumes of either normal rabbit serum, PTA antiserum or Hageman factor antiserum at $37^{\circ} \mathrm{C}$ for $30 \mathrm{~min}$. Residual activated PTA-like activity was assayed on bovine PTA-deficient plasma as described in Methods. The results were expressed as the clotting time and as the percent of the residual activated PTA-like activity relative to that in the mixture with normal rabbit serum. 
and Sephadex G-150. Therefore, the results with Amberlite-thrombin could be due to the presence of activated Hageman factor as a contaminant in thrombin preparations. The presence of activated Hageman factor in partially purified prothrombin preparations has been noted by Landaburu, Giavedoni, and Albado (25). Tissue thromboplastin was also tested, since Pitlick, Nemerson, Gottlieb, Gordon, and Williams (26) have recently shown that a purified tissue thromboplastin preparation has peptidase activity. Human and rabbit crude tissue thromboplastin at a concentration of 1 $\mathrm{mg} / \mathrm{ml}$ did not activate PTA during a period of incubation of $20 \mathrm{~min}$. Further, purified human placental tissue thromboplastin was without effect during a $90 \mathrm{~min}$ incubation period at $37^{\circ} \mathrm{C}$. The presence of unactivated PTA in the supernatant fluid after incubation and ultracentrifugation to remove tissue thromboplastin was demonstrated by the generation of activated PTA activity by the addition of Enzite-trypsin.

Gel filtration of PTA, Hageman factor-activated $P T A$, and trypsin-activated PTA. When unactivated PTA, PTA-activated by activated Hageman factor, or trypsin were separately filtered through a calibrated $2.6 \times 100 \mathrm{~cm}$ column of Sephadex G-150, all emerged at the same elution volume, suggesting that they all have the same molecular weight, approximately 185,000 (Fig. 6). This adds evidence that the clot-promoting agent evolved from PTA by trypsin was activated PTA. These experiments indicated that the conversion of PTA to clot-promoting agent does not appreciably alter the size of PTA under these conditions. This result is in good agreement with that of Donaldson and Ratnoff by sucrose density gradient centrifugation (13) and the more recent study of Ratnoff (16) by gel filtration on Sephadex G-150, in which crude PTA prepared from Hageman factor-deficient plasma was used.

\section{DISCUSSION}

PTA is the inert precursor of a clot-promoting agent participating early in the intrinsic pathway of thrombin formation in mammalian plasma. It is generally agreed that activated Hageman factor converts PTA to its activated form enzymatically and triggers a chain-reaction terminating in a solid fibrin formation. However, the absence of a bleeding tendency in Hageman factordeficient patients suggests that under some conditions PTA can become active in the absence of Hageman factor. Since the mechanism (s) of PTA activation by activated Hageman factor may be a limited proteolysis, several proteolytic enzymes including thrombin, plasmin. plasma kallikrein, and trypsin were tested for their possible ability to activate PTA. The experiments reported here provide support for the view that PTA can be activated by trypsin. Preparations of PTA purified

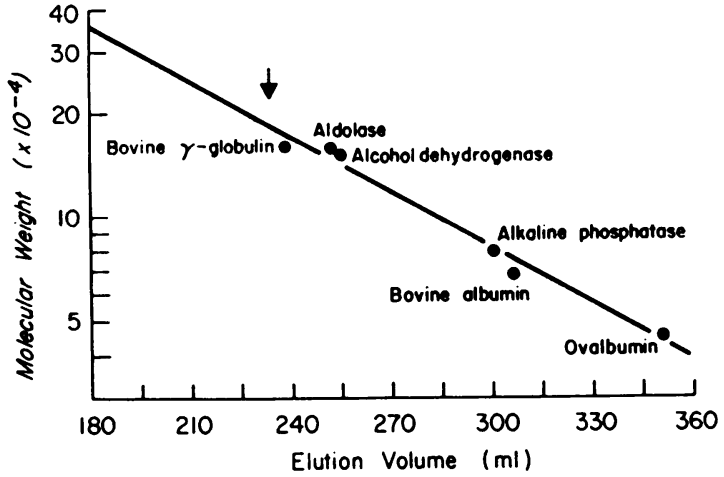

FIGLRE 6 The molecular weight estimation of native PTA, PTA activated by activated Hageman factor or trypsin by gel filtration (Sephadex G-150). The arrow indicates the position of elution of native PTA, PTA activated by activated Hageman factor or trypsin. The void volume of the column (estimated by the filtration of Blue dextran 2000) was $192 \mathrm{ml}$.

approximately 4500 -fold over normal human plasma. and devoid of detectable amounts of other clotting factors, generated potent clot-promoting activity when incubated with trypsin. The agent that evolved behaved like activated PTA, for it corrected the abnormally long clotting time of plasma deficient in Hageman factor or PTA but not plasma deficient in Christmas factor. Moreover, the clot-promoting agent behaved like activated PTA upon gel filtration through Sephadex G-150 and was specifically inhibited by an antiserum directed against activated PTA.

No evidence was obtained that suggested that the effect of trypsin was indirect, through an action upon Hageman factor contaminating the preparation of PTA. The absence of appreciable amounts of Hageman factor in such preparations was established both in clotting and immunologic assays. Further, no activation of the clot-promoting properties of Hageman factor was noted upon incubation with trypsin. The clot-promoting activity of the Hageman factor preparation evolved upon contact with glass decayed during its incubation with trypsin. These results also exclude the possibility that the preparation of trypsin used for PTA activation could have been contaminated with Hageman factor which might activate PTA. Several groups of investigators have reported that a low molecular weight (30.$000-40,000$ D) anionic substance (prealbumin or prekallikrein activator) can be derived from Hageman factor through treatment with plasmin or trypsin $(24,27$, $28)$. This substance activates prekallikrein but has only about $1 / 50^{\text {th }}$ the clot-promoting activity compared with the parent Hageman factor. The present study does not bear upon the formation of the prekallikrein activator but does confirm the inability of trypsin to induce formation of clot-promoting activity from Hageman factor. 
No evidence was obtained that autocatalytic activation of PTA could be induced by activated PTA, nor was activation brought about by incubation with human or bovine thrombin, plasma kallikrein, papain, plasmin, ficin, chymotrypsin, tissue thromboplastin, $\mathrm{C} \overline{1}$, or $\alpha$ amylase.

The activation of PTA by trypsin appeared to be enzymatic. The reaction was temperature dependent, the rate of generation of activated PTA was dependent upon the concentration of enzyme added, and the yield of activated PTA was a function of the concentration of PTA. Whatever the effect of trypsin, it was not associated with a major change in the molecular weight of PTA, as tested by gel filtration. This observation confirms earlier studies from this laboratory, using ultracentrifugation (13) and gel filtration (16). Presumably, the change in molecular size is too small to be measured in these crude ways, or, alternatively, the cleaved fragment or fragments do not completely separate from the parent molecule of PTA under the conditions used.

The present study was made feasible by the use of LBTI, an inhibitor of trypsin. In this situation, the enzyme must be neutralized by the addition of LBTI before clotting assays can be performed. The results of our studies were, therefore, confirmed through the use of insolubilized trypsin which can be removed from the reaction mixture before assays for clot-promoting activity are undertaken. Such water-insoluble enzymes have the disadvantage that they tend to exclude macromolecules because of the structure of the insoluble carrier, and may be, therefore, less active upon protein substrates compared with its soluble form.

Since only trace amounts of trypsin were necessary to activate PTA, the possibility exists that the enzyme may carry out this function within the body. Under normal conditions, trypsin cannot be detected in mammalian blood. Perhaps, however, trypsin may be released into the blood stream under pathologic conditions, such as pancreatitis, and can then activate PTA as well as Stuart factor and prothrombin, two other known substrates (29).

The experiments described lend some support to the view that the absence of hemorrhagic symptoms in Hageman trait bespeaks the presence of an alternative mechanism for initiation of clotting via the intrinsic pathway. The nature of the proteolytic enzyme responsible for activation of PTA in the absence of Hageman factor remains to be determined. It should be noted, however that other explanations for the absence of bleeding symptoms in Hageman trait are possible. For example, Nemerson and Pitlick (30) proposed recently that low or immeasurable levels of Hageman factor may be concentrated to hemostatically effective levels by their high affinity for damaged tissue.

\section{ACKNOWLEDGMENTS}

Ms. Janet Shlaes and Ms. Carol Slover provided invaluable technical help.

This study was supported in part by grants HL 01661 and AM 15308 from the National Institutes of Health, U. S. Public Health Service, and in part by grants from the American Heart Association.

\section{REFERENCES}

1. Ratnoff, O. D., E. W. Davie, and D. L. Mallett. 1961. Studies on the action of Hageman factor. Evidence that activated Hageman factor in turn activates plasma thromboplastin antecedent. J. Clin. Invest. 40: 803 .

2. Nossel, H. L. 1964. Contact Phase of Blood Coagulation. Blackwell Scientific Publications, Ltd., Oxford.

3. Forbes, C. D., and O. D. Ratnoff. 1972. Studies on plasma thromboplastin antecedent (factor XI), PTA deficiency and inhibition of PTA by plasma, pharmacologic inhibitors and specific antiserum. J. Lab. Clin. Med. 79: 113 .

4. Ratnoff, O. D. 1966. The biology and pathology of the initial stages of blood coagulation. Prog. Hematol. 5: 204.

5. Wuepper, K. D. 1972. Precursor plasma thromboplastin antecedent (PTA, clotting factor XI). Fed. Proc. 31 : 624. (Abstr.)

6. Kociba, G. J., O. D. Ratnoff, W. F. Loeb, R. L. Wall, and L. E. Heider. 1969. Bovine plasma thromboplastin antecedent (Factor XI) deficiency. J. Lab. Clin. Med. $74: 37$.

7. Ogston, D., C. M. Ogston, O. D. Ratnoff, and C. D. Forbes. 1969. Studies on a complex mechanism for the activation of plasminogen by kaolin and by chloroform: the participation of Hageman factor and additional cofactors. J. Clin. Invest. 48: 1786.

8. Zimmerman, T. S., O. D. Ratnoff, and A. E. Powell 1971. Immunologic differentiation of classic hemophilia (Factor VIII deficiency) and von Willebrand's disease. J. Clin. Invest. $50: 244$.

9. Prentice, C. R. M., O. D. Ratnoff, and R. T. Breckenridge. 1967. Experiments on the nature of the prothrombin-converting principle: Alteration of proaccelerin by thrombin. Br. J. Haematol. $13: 898$.

10. Berg, W., K. Korsan-Bengtsen, and J. Ygge. 1966. Preparation of human plasminogen suitable as substrate for quantitative determination of plasminogen activators. Thromb. Diath. Haemorrh. 15 : 511.

11. Kline, D. L., and J. B. Fishman. 1961. Proactivator function of human plasmin as shown by lysine esterase assay. J. Biol. Chem. 236: 2807.

12. Cuatrecasas, P. 1970 . Protein purification by affinity chromatography. Derivatizations of agarose and polyacrylamide beads. J. Biol. Chem. 245: 3059.

13. Donaldson, V. H., and O. D. Ratnoff. 1965. Hageman factor: Alterations in physical properties during activation. Science (Wash. D. C.). 150: 754.

14. Forbes, C. D., J. Pensky, and O. D. Ratnoff. 1970. Inhibition of activated Hageman factor and activated plasma thromboplastin antecedent by purified serum $\overline{C 1}$ inactivator. J. Lab. Clin. Med. 76: 809.

15. Ratnoff, O. D., and G. B. Naff. 1967. The conversion of $\mathrm{C}^{\prime} 1 \mathrm{~S}$ to $\mathrm{C}^{\prime} 1$ esterase by plasmin and trypsin. J. Exp. Med. 125 : 337.

16. Ratnoff, O. D. 1972. Studies on the product of the reaction between activated Hageman factor (Factor XII) 
and plasma thromboplastin antecedent (Factor XI). J. Lab. Clin. Med. 80: 704.

17. Kass, L., O. D. Ratnoff, and M. A. Leon. 1969. Studies on the purification of antihemophilic factor (Factor VIII). I. Precipitation of antihemophilic factor by concanavalin A. J. Clin. Invest. 48: 351.

18. Ogston, D., N. B. Bennett, C. M. Ogston, and O. D. Ratnoff. 1971. The assay of a plasma component necessary for the generation of a plasminogen activator in the presence of Hageman factor (Hageman factor cofactor). Br. J. Haematol. 20: 209.

19. Siegelman, A. M., A. S. Carlson, and T. Robertson. 1962. Investigation of serum trypsin and related substances. I. The quantitative demonstration of trypsinlike activity in human blood serum by a micromethod. Arch. Biochem. Biophys. 97: 159.

20. Ratnoff, O. D., J. Pensky, D. Ogston, and G. B. Naff. 1969. The inhibition of plasmin, plasma kallikrein, plasma permeability factor, and the $C \overline{1} \mathrm{r}$ subcomponent of the first component of complement by serum $C^{\prime} 1$ esterase inhibitor. J. Exp. Med. 129: 315.

21. Garen, A., and C. Levinthal. 1960. A fine-structure genetic and chemical study of the enzyme alkaline phosphatase of E. coli. I. Purification and characterization of alkaline phosphatase. Biochim. Biophy's. Acta. 38: 470.

22. Andrews, P. 1965. The gel-filtration behaviour of proteins related to their molecular weights over a wide range. Biochem. J. $96: 595$.
23. Lowry, O. H., N. J. Rosebrough, A. L. Farr, and R. J. Randall. 1951. Protein measurement with the Folin phenol reagent. J. Biol. Chem. 193: 265.

24. Soltay, M. J., H. Z. Movat, and A. H. Özge-Anwar. The Kinin System of Human Plasma. V. The probable derivation of Prekallikrein activator from activated Hageman Factor (XIIa). Proc. Soc. Exp. Biol. Med. 138: 952.

25. Landaburu, R. H., E. Giavedoni, and E. Albado. 1971. Factor XII in bovine prothrombin preparations: a purication procedure. Coagulation. 4: 131.

26. Pitlick, F. A., Y. Nemerson, A. J. Gottlieb, R. G. Gordon, and W. J. Williams. 1971. Peptidase activity associated with the tissue factor of blood coagulation. Biochemistry. 10: 2650

27. Kaplan, A. P., and K. F. Austen. 1971. A prealbumin activator of prekallikrein. II. Derivation of activators of prekallikrein from active Hageman factor by digestion with plasmin. J. Exp. Med. 133: 696.

28. Cochrane, C. G., and K. D. Wuepper. 1971. The first component of the kinin-forming system in human and rabbit plasma. Its relationship to clotting factor XII (Hageman Factor). J. Exp. Med. 134: 986.

29. Alexander, B., L. Pechet, and A. Kliman. 1962. Proteolysis, fibrinolysis and coagulation significance in thrombolytic therapy. Circulation. 26: 596.

30. Nemerson, Y., and F. A. Pitlick. 1972. The tissue factor pathway of blood coagulation. In Progress in Hemostasis and Thrombosis. T. H. Spaet, editor. Grune \& Stratton, Inc., New York. 